The age and provenance of the three deep sequences are entirely conjectural. It seems likely that the uppermost sequence corresponds to what was called Megasequence 2 in the Pilot Study (Chalmers, 1989) and it may well be of Late Cretaceous age. The lower two sequences could correspond to the lower more reflective and upper more transparent sequences in Megasequence 1 of the Pilot Study.

The upper two sequences can be correlated with the presumed Cretaceous sequences present on either side of the Kangâmiut ridge (fig. 2), but the lowermost sequence is present only in a narrow outlier between $64^{\circ} 45^{\prime} \mathrm{N}$ and $65^{\circ} 15^{\prime}$ and in a more extensive area of fault blocks between $64^{\circ} 45^{\prime} \mathrm{N}$ and the southern limit of data coverage at $64^{\circ} 20^{\prime} \mathrm{N}$ (fig. 1).

It is hoped that new data will be acquired in 1990 which will enable these sequences to be interpreted to the south, to find what is their relationship to the sequences in the Pilot Study area and to extend that interpretation farther south (see following article).

\section{References}

Chalmers, J. A. 1989: A pilot seismo-stratigraphic study on the West Greenland continental shelf. Rapp. Grønlands geol. Unders. 142, $16 \mathrm{pp}$.

Hald, N. \& Larsen, J. G. 1987: Early Tertiary, low-potassium tholeiites from exploration wells on the West Greenland shelf. Rapp. Grønlands geol. Unders. 136, $25 \mathrm{pp}$.

Henderson, G., Schiener, E. J., Risum, J. B., Croxton, C. A. \& Andersen, B. B. 1981: The West Greenland Basin. In Kerr, J. W. \& Ferguson, A. J. (edit.) Geology of the North Atlantic Borderlands. Mem. Can. Soc. Petrol. Geol. 7, 399428.

Manderscheid, G. 1980: The geology of the offshore sedimentary basin of West Greenland. In Miall, A. D. (edit.) Facts and principles of world oil occurrence. Mem. Can. Soc. Petrol. Geol. 6, 951-973.

Ottesen, T. G. 1989: Seismisk stratigrafisk fortolkning offshore Vest Grønland. Unpubl. cand. scient. thesis, Institute of Geophysics, Copenhagen University, $144 \mathrm{pp}$.

Rolle, F. 1985: Late Cretaceous - Tertiary sediments offshore central West Greenland: lithostratigraphy, sedimentary evolution, and petroleum potential. Can. J. Earth Sci. 22, 10011019.

J. A. C., Geological Survey of Greenland, Copenhagen.

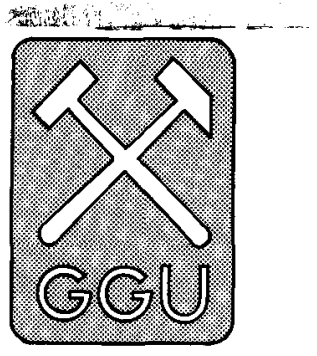

\title{
Regional marine seismic reconnaissance
}

\author{
Hans Christian Larsen and T. C. R. Pulvertaft
}

The only offshore multi-channel reflection seismic survey that has been carried out by GGU until now is project NAD (North Atlantic D), a survey which covered most of the eastern Greenland shelf between $63^{\circ}$ and $72^{\circ} \mathrm{N}$ (Larsen, 1985, in press). This survey was made possible by a large grant from the EEC. After Greenland's withdrawal from the EC in 1985 it became doubtful if support for further major projects offshore Greenland could be obtained from the EEC. Other sources of funding would have to be found if the costly process of investigating the hydrocarbon potential of the vast continental shelf off Greenland was to continue. Against this background the Mineral Resources Administration for Greenland requested GGU and $\mathrm{Nu}$ naoil A/S (the joint Greenland Home Rule/Danish
State-owned company) to work out alternative plans for carrying out and financing marine seismic data acquisition offshore Greenland, and in 1986 GGU proposed the KANUMAS project (Larsen, 1986). KANUMAS is an acronym for Kalaallit Nunaat Marine Seismic; Kalaallit Nunaat is the Greenlandic name for Greenland.

\section{Project KANUMAS}

The essence of the original KANUMAS project proposal was as follows.

A regional reconnaissance seismic survey using modern technology would be carried out over the entire shelf off eastern and western Greenland, with the exception of the areas sufficiently covered by the NAD 


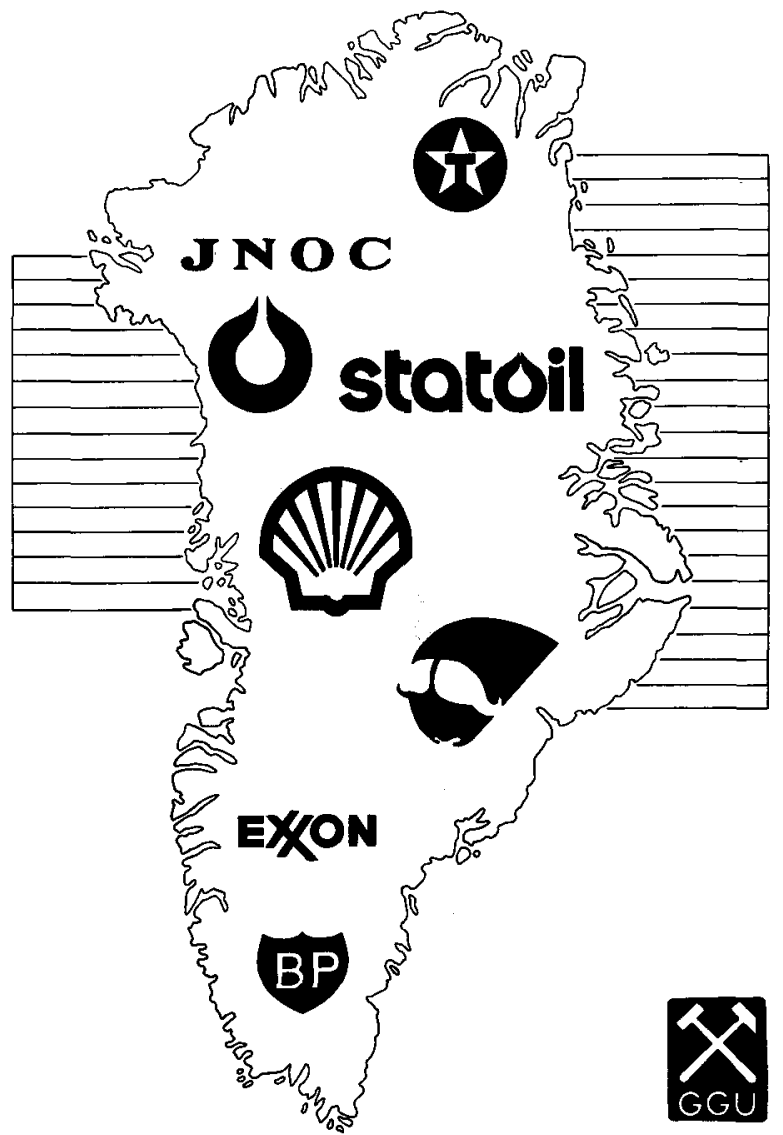

Fig. 1. The KANUMAS project aims to acquire and interpret reflection seismic data from offshore areas both to the west and east of Greenland (shaded). The project is scheduled for the period 1990-95 and is funded by the following six companies: British Petroleum Development, Den norske stats oljeselskab (Statoil), Esso Exploration, Japan National Oil Corporation, Shell, and Texaco Exploration. The Greenland-Danish company, Nunaoil $A / S$, is the seventh member, and is operator for the group which has been granted a prospecting license to carry out the project. The Geological Survey of Greenland (GGU) originally described the project and will act as principal geological and geophysical project advisor. GGU will also supervise the field work, processing and interpretation of geophysical data and geological reporting associated with the project.

survey. In all c. 22000 line $\mathrm{km}$ of new data should be acquired over a period of six years, with a line spacing averaging about $40 \mathrm{~km}$. Due to the unpredictability of ice conditions off eastern Greenland, no detailed plan or priority for the order in which the different parts of the shelf would be surveyed was made; the final decision as to where the seismic vessel should be sent each season would be made about a month before the start of each cruise. The object of the survey, with its wide line spacing, would be to gain an overview of the general potential of offshore Greenland, whether indications of the presence of sedimentary basins are correct, and which of these basins are large enough and suitably structured to host hydrocarbon reserves.

Financing of the survey was to be by industry, either by meeting the costs of the survey directly or through the sale of data, or both. Nunaoil A/S was required by the Mineral Resources Administration to be operator for the survey and to be responsible for the economic and contractual part of the project, while GGU would be principal technical advisor and be responsible for planning and directing field operations and interpretation of the data.

At first it seemed that 8 or 9 major companies might be prepared to join in the financing of the project, but interest then dwindled following a general weakening of the market and fall in oil prices, and it was not possible to resume serious negotiations with companies before the winter of 1988/89. In January 1989 six companies had declared themselves seriously interested in the project under the terms being offered, and detailed planning could begin. However, with the reduction of the number of companies to 6 , funds available for the project were also reduced, and consequently the original plan to shoot $22000 \mathrm{~km}$ had to be reduced to 13500 $\mathrm{km}$. At the request of the participating companies, the western Greenland shelf south of $70^{\circ} \mathrm{N}$, where old industry data exist (see the previous article), was taken out of the project, while the original plan for the survey in eastern Greenland remained intact. However, this has reduced the chances of successfully completing the eastern programme, as with the removal of the southern West Greenland shelf from the project, much of the operational flexibility of the original full programme has been lost. In the original full programme southern West Greenland provided an alternative operational area in years with severe ice conditions off East and North-East Greenland.

In the reduced KANUMAS project, data acquisition is to take place over four ship-seasons, one off NorthWest Greenland (Melville Bugt), and three off NorthEast Greenland - with supplementary lines as far south as $68^{\circ} \mathrm{N}$ in areas missed by the NAD survey on account of ice conditions. Briefly, the reasons for believing that these areas have prospective potential are as follows.

North-West Greenland (Melville Bugt): A very strong negative gravity anomaly has been recorded in an elongate area stretching SSE from Kap York in Melville Bugt (Ross \& Henderson, 1973). Covering about the same area there is a negative magnetic anomaly (Hood $\&$ Bower, 1973). Together these suggest an up to $8 \mathrm{~km}$ thick sedimentary basin in this area. An oil seep on the sea floor on the opposite side of Baffin Bay (MacLean $e t$ 
$a l ., 1981$ ), and the occurrence of potential oil source rocks onshore West Greenland on the Nûgssuaq and Svartenhuk peninsulas are encouraging signs that source rocks might be found in such a basin.

North-East Greenland: The aeromagnetic survey EASTMAR revealed the presence on the North-East Greenland shelf of elongate areas with depth to magnetic basement up to more than $8 \mathrm{~km}$ (Thorning et al., 1982). These areas are probably sedimentary basins, although the age of the sediments could be anything from Late Proterozoic to Tertiary (Larsen, 1984, 1985, in press). However, when the continents have been restored to their position prior to the opening of the North Atlantic and Greenland Sea, the North-East Greenland shelf lies on line with the oil-producing areas of the North Sea and adjacent to highly prospective areas on the Norwegian shelf. Furthermore, good source rocks occur at several stratigraphic levels onshore North-East Greenland. Expectations for the North-East Greenland shelf are therefore high.

\section{Project SYD VEST SEIS}

Although there are grounds for optimism about the hydrocarbon potential of Melville Bugt and offshore North-East Greenland, it must be remembered that ice conditions in these areas are very severe. Detailed seismic prospecting here is outside what can be achieved with existing technology (Chalmers, 1990), and hydrocarbon exploitation in these areas cannot be expected in the first 20 years or even longer in the case of NorthEast Greenland. For this reason GGU finds it of paramount importance to continue investigations in the less demanding West Greenland shelf (see the previous article).

A seismic survey (project SYD VEST SEIS) is to be carried out during the summer of 1990 and financed jointly by the Mineral Resources Administration for Greenland and GGU. A commercial seismic contractor will be used to acquire and process the data.

Project VEST SOKKEL (see previous article) has shown that there are several areas offshore southern West Greenland which have the potential to contain hydrocarbons. However, additional seismic data are required to extend or refine our understanding of them. Project SYD VEST SEIS will acquire $3355 \mathrm{~km}$ of multichannel seismic and magnetic data for the following reasons (see figs $1 \& 2$ of the previous article for locations):

- to investigate the areas of poor data coverage south of $64^{\circ} 20^{\prime} \mathrm{N}$;
- to improve the understanding of the structural development of the Kangâmiut ridge and the area to the west of it;

- to investigate the area to the south of the Kangâmiut ridge and west of the Nukik wells, which may contain interesting fault blocks;

- to examine the nature of the (possibly compressional) structures around Ikermiut-1;

- to examine the deep sedimentary section between $67^{\circ}$ and $68^{\circ} \mathrm{N}$;

- to attempt to penetrate with seismic energy the Tertiary basalts west and south-west of Disko Bugt in order to examine whether there are sediments and structures below them.

Once processed, the data will be interpreted by GGU. They will also be available for sale.

\section{References}

Chalmers, J. A. 1990: Seismic acquisition in sea ice - How can we start to explore offshore East Greenland? First Break 8(2), 51-56.

Hood, P. [J.] \& Bower, M. E. 1973: Low-level aeromagnetic surveys of the continental shelves bordering Baffin Bay and the Labrador Sea. In Hood, P. J. (edit.) Earth science symposium on offshore eastern Canada. Pap. geol. Surv. Can. 71-23, 573-598.

Larsen, H. C. 1984: Geology of the East Greenland shelf. In Spencer, A. M. (edit.) Petroleum geology of the north European margin, 329-339. Oslo: Norwegian Petroleum Society and Graham \& Trotman.

Larsen, H. C. 1985: Petroleum geological assessment of the East Greenland shelf, 78 pp. plus appendices. Copenhagen: Geol. Surv. Greenland.

Larsen, H. C. 1986: Project KANUMAS. Proposal for a regional marine seismic survey around Greenland: geophysical description, 38 pp. Copenhagen: Geol. Surv. Greenland.

Larsen, H. C. in press: The East Greenland shelf. In Grantz, A., Johnson, [G.] L. \& Sweeney, J. F. (edit.) The Arctic Ocean region. The geology of North America L. Boulder, Colorado: Geol. Soc. America.

MacLean, B., Falconer, R. K. H. \& Levy, E. M. 1981: Geological, geophysical and chemical evidence for natural seepage of petroleum off the northeast coast of Baffin Island. Bull. Can. Petrol. Geol. 29, 75-95.

Ross, D. I. \& Henderson, G. 1973: New geophysical data on the continental shelf of central and northern West Greenland. Can. J. Earth Sci. 10, 485-497.

Thorning, L., Larsen, H. C. \& Jacobsen, N. L. 1982: Project EASTMAR - final report, 82 pp. Copenhagen: Geol. Surv. Greenland.

H. C. L. \& T. C. R. P., Geological Survey of Greenland, Copenhagen. 